\title{
PENGARUH KECERDASAN INTRAPERSONAL DAN KEDISIPLINAN BELAJAR TERHADAP PRESTASI BELAJAR MATEMATIKA
}

\author{
Farel Zefanya \\ SMK Farmasi Bakthi Negeri Jakarta Timur
}

\section{INFO ARTICLES}

Article History:

Received: 29 April 2018

Revised: 11 Mei 2018

Approved: 18 Mei 2018

Publish Online: 25 Mei 2018

\section{Key Words:}

Mathematics Achievement, structured Dyadic Method, Brain Gym Method.

\section{(1) (2)}

\begin{abstract}
: the purpose of this study is to know: 1) the impacts of intrapersonal question and learning discipline on mathematics learning achievement all together.2) the impacts of intrapersonal question on mathematics learning achievement,3) the impacts of learning discipline on mathematics learning achievement. The methode used is correlational survey on the students of class $x$ at SMK Raflesia Depok, at academic years 2015/2016. Sample is taken by simple random sampling technique from 40 respondents. Data collecting instrument used quisionaire for intrapersonal question and learning discipline and test instrument for mathematics learning achievement. Data is analyzed with test requirement analysis i.e normality test, linearity test and multicolineairity test. After test requirement fulfilled, the writer did inferensial analysis for hypothesis test by using double inferensial analysis. Based on the result show that: 1) there are impacts of intrapersonal question and learning discipline on mathematics learning achievement all together. 2) there are impacts of intrapersonal question on mathematics learning achievement. 3) there are impacts of learning discipline on mathematics learning achievement.
\end{abstract}

\begin{abstract}
Abstrak: Tujuan dari penelitian ini adalah untuk mengetahui: (1) pengaruh kecerdasan intrapersonal dan kedisiplinan belajar secara bersama-sama terhadap prestasi belajar matematika; (2) pengaruh kecerdasan intrapersonal terhadap prestasi belajar matematika; dan (3) pengaruh kedisiplinan belajar terhadap prestasi belajar matematika. Metode penelitian yang digunakan adalah survei korelasional yang dilakukan pada siswa kelas X di SMK Raflesia Depok tahun ajaran 2015/2016. Sampel diambil dengan teknik simple random sampling sebanyak 40 responden. Instrumen pengumpulan data dengan penyebaran angket untuk mengukur kecerdasan intrapersonal dan kedisiplinan belajar, sedangkan prestasi belajar matematika menggunakan instrumen tes. Data hasil penelitian dianalisis terlebih dahulu dengan uji persyaratan analisis, yaitu uji normalitas, uji linieritas, dan uji multikolinieritas. Setelah uji persyaratan analisis data terpenuhi, dilakukan analisis inferensial untuk pengujian hipotesis penelitian dengan menggunakan analisis regresi ganda. Dari hasil penelitian ditemukan bahwa: (1) terdapat pengaruh kecerdasan intrapersonal dan kedisiplinan belajar secara bersama-sama terhadap prestasi belajar matematika; (2) terdapat pengaruh kecerdasan intrapersonal terhadap prestasi belajar matematika; (3) terdapat pengaruh kedisiplinan belajar terhadap prestasi belajar matematika.
\end{abstract}

Correspondence Address: Jln. Belly/Mekar V RT.07/09, Kel. Cijantung, Kec. Pasar Rebo, RT.7/RW.9, Cijantung, Kota Jakarta Timur, Daerah Khusus Ibukota Jakarta, Indonesia. email: farel8001.zefanya@ gmail.com

How to Cite (APA 6 ${ }^{\text {th }}$ Style): Zefanya, F. (2018). Pengaruh Tingkat Kesejahteraan Keluarga dan Kecerdasan Emosional Siswa terhadap Prestasi Belajar Matematika. JKPM (Jurnal Kajian Pendidikan Matematika), 03(02): 135144.

Copyright: Zefanya, F. (2018)

Competing Interests Disclosures: The authors declare that they have no significant competing financial, professional or personal interests that might have influenced the performance or presentation of the work described in this manuscript. 


\section{PENDAHULUAN}

Di era globalisasi, pendidikan memegang peranan yang sangat penting dalam kemajuan IPTEK di Indonesia. Menurut Rohim, dkk. (dalam Leonard, dkk., 2015: 94) mengemukakan bahwa: "pesatnya laju perkembangan Ilmu Pengetahuan dan Teknologi merupakan manfaat dari pendidikan dalam meningkatkan kualitas sumber daya manusia pada suatu negara dan juga perkembangan Ilmu Pengetahuan dan Teknologi dalam bermasyarakat dan bernegara ternyata mempunyai dampak yang positif dan negatif'. Maka dari itu, untuk mewujudkan kemajuan pendidikan di Indonesia diperlukan peningkatan dan penyempurnaan penyelenggaraan pendidikan nasional. Tidak hanya pemerintah yang terlibat untuk meningkatkan mutu pendidikan nasional, peran dari orang tua, guru, masyarakat dan lingkungan turut andil dalam memajukan pendidikan nasional. Dengan adanya sinergi dari berbagai pihak, diharapkan kemajuan pendidikan nasional akan tercapai.

Namun kenyataannya, kualitas pendidikan di Indonesia masih jauh tertinggal dibandingkan dengan negara-negara lainnya. Hal ini berdasarkan data dari survai untuk kerjasama ekonomi dan pembangunan (OECD) yang dilangsir dari situs klik positif menyatakan bahwa Indonesia berada pada peringkat ke-69 dari 76 negara. Bahkan Indonesia masih kalah bersaing dengan empat negara ASEAN lainnya seperti Singapura, Vietnam, Malaysia, dan Thailand. Berdasarkan hal ini, bukan berarti pendidikan Indonesia tidak memiliki prestasi di kancah Internasional. Ini terbukti dari kejuaraan olimpiade matematika dan sains, yang diselenggarakan oleh the Wizards at Mathematics International Competition (WIZMIC) 2014, di Lucknow, India yang dilangsir dari situs metrotvnews. Pada olimpiade ini, tim olimpiade Matematika dan Sains Indonesia mampu menjadi juara umum yang diikuti oleh 43 negara pada kejuaraan tersebut yang diselenggarakan pada tanggal 18-21 Oktober 2014.

Oleh karena itu, kita harus tetap optimis terhadap generasi-generasi muda penerus bangsa ini agar bisa berbicara lebih banyak di dunia internasional. Sehingga bangsa Indonesia tidak akan diremehkan oleh negara-negara lainnya. Berbagai upaya untuk meningkatkan kualitas pendidikan di Indonesia tidak pernah berhenti dilakukan. Berbagai terobosan baru terus dilakukan oleh pemerintah, antara lain dalam pengelolaan sekolah, peningkatan sumber daya tenaga pendidikan, pengembangan dan penulisan materi ajar, serta pengembangan paradigma baru dengan metodologi pengajaran.

Dalam kegiatan belajar mengajar, selalu terjadi keterkaitan dan interaksi antara guru yang mengajar dan siswa yang belajar. Menurut Hamalik (2001: 44), "Istilah mengajar dan belajar adalah dua peristiwa yang berbeda, akan tetapi antara keduanya terdapat hubungan yang erat sekali bahkan antara keduanya terjadi keterkaitan dan interaksi satu sama lain." Sesungguhnya, mengajar bukanlah semata persoalan menceritakan. Namun lebih dari itu, mengajar adalah suatu kegiatan yang bertujuan untuk menyampaikan suatu pengetahuan atau informasi kepada siswa. Hal ini senada dengan Hamalik (2001: 44) yang mengemukakan bahwa: "Mengajar ialah menyampaikan pengetahuan kepada siswa atau murid di sekolah, sedangkan belajar merupakan keterlibatan mental dan kerja siswa sendiri." Hal ini juga senada dengan Siregar dan Nara (2010: 5) yang mengemukakan bahwa: "Belajar adalah suatu aktivitas mental (psikis) yang berlangsung dalam interaksi dengan lingkungannya yang menghasilkan perubahan yang bersifat relatif konstan". 
Penjelasan dan pemeragaan semata tidak akan membuahkan hasil belajar yang langgeng. Terutama dalam pelajaran Matematika karena Matematika merupakan disiplin ilmu dasar dari berbagai disiplindisiplin ilmu lainnya. Artinya, Matematika adalah sebuah cabang ilmu yang menjadi dasar dalam cabangcabang ilmu lainnya. Tidak ada satu cabang ilmu pun tanpa melibatkan Matematika. Selain itu, Matematika juga merupakan pelajaran yang berperan penting, baik penerapannya dalam kehidupan sehari- hari dan pengembangan kehidupan lainnya.

Sesungguhnya dalam mempelajari pelajaran matematika, siswa seharusnya ditanamkan konsep terlebih dahulu. Karena dengan menanamkan konsep kepada siswa, maka siswa akan dapat menyelesaikan persoalan-persoalan yang berkaitan tentang pelajaran Matematika. Zulkardi (dalam Murizal, dkk., 2012: 20) mengemukakan bahwa: "Mata pelajaran matematika menekankan pada konsep". Di sinilah peran guru, guru harus mampu memberikan pengajaran yang dimana konsep menjadi pondasi utama dalam mempelajari Matematika. Karena tujuan pengajaran itu sendiri adalah mampu memberikan suatu pengetahuan kepada siswa. Hal ini senada dengan Hudoyo (dalam Murizal, dkk., 2012: 19) yang mengemukakan bahwa: "Tujuan mengajar adalah agar pengetahuan yang disampaikan dapat dipahami peserta didik". Namun, keberhasilan dalam mencapai prestasi belajar matematika di sekolah tidak cukup hanya dengan mengandalkan dari kemampuan guru dalam mengolah proses belajar mengajar di kelas. Akan tetapi, dapat juga dipengaruhi oleh faktor siswa itu sendiri. Hal ini senada dengan Slameto (2013: 54) yang mengemukakan bahwa: "Faktor-faktor yang mempengaruhi belajar banyak jenisnya, tetapi dapat digolongkan menjadi dua golongan saja, yaitu faktor intern dan ekstern".

Dari sekian banyak faktor-faktor tersebut, kecerdasan merupakan salah satu faktor yang paling mempengaruhi prestasi belajar siswa. Pada dasarnya, setiap siswa memiliki kecerdasan yang berbeda-beda. Hal ini senada dengan konsep kecerdasan majemuk yang dijelaskan oleh Gardner (dalam Supardi, 2014: 82), "Kecerdasan seseorang meliputi unsur-unsur kecerdasan matematika logika, kecerdasan bahasa, kecerdasan musikal, kecerdasan visual spasial, kecerdasan kinestetis, kecerdasan interpersonal, kecerdasan intrapersonal, dan kecerdasan naturalis". Salah satunya adalah kecerdasan intrapersonal. Kecerdasan intrapersonal sangat berperan penting dalam mempelajari matematika. Dalam proses belajar matematika tidak hanya sekedar menghitung rumus matematika atau penggunaan logika, tetapi lebih dari itu. Untuk menemukan makna suatu rumus matematika perlu perenungan yang mendalam untuk hal itu. Selain itu, belajar matematika juga harus ada motivasi dalam diri individu secara konsisten. Hal ini sesuai dengan pendapat Adriyati dan Nursa'adah (dalam Leonard, dkk., 2015: 390) yang mengemukakan bahwa: "Setiap anak memiliki porsi berbeda-beda, kendati tidak memiliki kecerdasan tinggi dalam bermusik atau matematika, namun anak memiliki kemampuan untuk mengoptimalkan kemampuannya dengan cara giat berlatih, intropeksi kesalahan dan memotivasi diri sendiri”.

Selain kecerdasan, kedisiplinan belajar juga mempengaruhi prestasi belajar siswa. Kedisiplinan belajar merupakan faktor internal yang dapat mempengaruhi prestasi belajar siswa karena timbul dari diri siswa itu sendiri. Dengan menimbulkan rasa disiplin kepada siswa dalam proses pembelajaran akan memberikan manfaat dan jalan kepada siswa untuk sukses dalam belajar. Hal ini senada dengan Tu'u (dalam Supardi, 2014: 82) yang mengemukakan bahwa: "Disiplin merupakan jalan bagi siswa untuk sukses dalam belajar dan kelak ketika bekerja." Oleh karena itu, dibutuhkan berbagai kreativitas baru bagi guru untuk menciptakan situasi pembelajaran di mana berbagai jenis kecerdasan siswa dapat dikembangkan, bukan 
hanya secara tunggal memiliki kecerdasan tertentu, melainkan juga jenis kecerdasan lainnya, walaupun harus diakui pula bahwa terdapat satu atau lebih kecerdasan yang lebih menonjol pada diri siswa. Selain itu, guru juga harus menanamkan sikap disiplin kepada siswa agar kemampuan dan kecerdasan yang dimiliki oleh siswa dapat berkembang secara optimal. Dengan demikian, upaya pengembangan kemampuan siswa dengan mengintegrasikan aktivitas pembelajaran berbasis intrapersonal dan penanaman sikap disiplin belajar yang tinggi akan melahirkan generasi yang baik.

Berdasarkan uraian di atas, secara keseluruhan penelitian ini bertujuan untuk mengetahui pengaruh kecerdasan intrapersonal dan kedisiplinan belajar secara bersama-sama terhadap prestasi belajar matematika, untuk mengetahui pengaruh kecerdasan intrapersonal terhadap prestasi belajar matematika, dan untuk mengetahui pengaruh kedisiplinan belajar terhadap prestasi belajar matematika pada siswa kelas $\mathrm{X}$ Kesehatan di SMK Raflesia Tahun Ajaran 2015/2016.

\section{METODE}

Penelitian ini dilaksanakan di SMK Raflesia yang terletak di Jalan Mahkota Raya No.32B Pondok Duta, Cimanggis, Depok, Jawa Barat. Penelitian ini dilaksanakan pada semester genap tahun ajaran 2015/2016 yang membutuhkan waktu selama 2 bulan, yaitu pada bulan Februari sampai bulan Mei. Metode dalam penelitian ini adalah metode survei dengan analisis korelasional. Desain penelitian yang digunakan adalah regresi ganda dengan desain penelitian sebagai berikut:

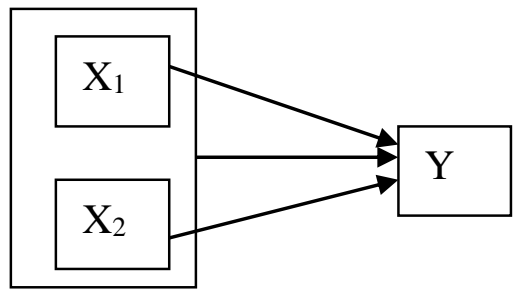

Gambar 1. Desain Penelitian

Sampel yang digunakan pada penelitian ini berjumlah 40 responden yang diambil dengan teknik simple random sampling, di mana pengambilan sampel dari populasi secara acak tanpa memperhatikan strata atau tingkatan karena anggota populasi dianggap homogen. Teknik pengumpulan data yang digunakan dalam penelitian ini adalah untuk kecerdasan intrapersonal dan kedisiplinan belajar dengan penyebaran angket, sedangkan data prestasi belajar matematika siswa diambil dari hasil tes uji soal. Uji coba instrumen dilakukan kepada responden lain yang tidak dijadikan sampel. Data dianalisis terlebih dahulu dengan uji persyaratan, yaitu uji normalitas, uji linieritas, dan uji multikolinieritas. Jika persyaratan analisis data sudah terpenuhi, maka dilakukan analisis inferensial untuk pengujian hipotesis penelitian. Analisis inferensial menggunakan teknik analisis regresi ganda. 


\section{HASIL}

Berdasarkan hasil analisis data untuk prestasi belajar matematika diperoleh rata-rata mean sebesar 73,38; median sebesar 75,14; modus sebesar 78,44; simpangan baku sebesar 11,82; dan Varians sebesar 139,93. Berdasarkan hasil ini dapat disimpulkan bahwa prestasi belajar matematika siswa dari hasil uji tes sangat baik dengan perolehan nilai tertinggi 100 dan nilai terendah 48. Sementara hasil analisis data untuk kecerdasan intrapersonal diperoleh rata-rata sebesar 94,2; median sebesar 94,74; modus sebesar 96,24; simpangan baku sebesar 8,50 dan Varians sebesar 72,25. Berdasarkan hasil ini dapat disimpulkan bahwa siswa kelas $X$ Kesehatan memiliki kecerdasan intrapersonal yang tinggi. Selain itu, hasil analisis data kedisiplinan belajar diperoleh rata-rata sebesar 97,3; median sebesar 97,94; modus sebesar 98,5; simpangan baku sebesar 11,37 dan Varians sebesar 129,17. Berdasarkan hal ini dapat disimpulkan bahwa siswa kelas $\mathrm{X}$ kesehatan memiliki sikap disiplin yang tinggi.

Sebelum dilakukan pengujian hipotesis, terlebih dahulu dilakukan pengujian persyaratan analisis data yang terdiri dari uji normalitas, uji linieritas, dan uji multikolinieritas. Pengujian normalitas dilakukan untuk mengetahui distribusi data sampel setiap variabel yang diteliti apakah berasal dari populasi yang berdistribusi normal atau tidak. Pegujian normalitas dilakukan dengan uji Chi Kuadrat, dengan kriteria pengujian adalah jika $X_{\text {hitung }}^{2}<X_{\text {tabel }}^{2}$ maka data berdistribusi normal, dan jika $X_{\text {hitung }}^{2}>X_{\text {tabel }}^{2}$ maka data tidak berdistribusi normal. Untuk besarnya $X_{\text {tabel }}^{2}$ untuk taraf signifikasnsi $\alpha=0,05$ dan $\mathrm{dk}=\mathrm{k}-1=6-1$ $=5$, diperoleh nilai $X_{\text {tabel }}^{2}=11,070$. Berdasarkan perhitungan uji normalitas prestasi belajar matematika diperoleh nilai $X_{\text {hitung }}^{2}=-15,799$ dan $X_{\text {tabel }}^{2}=11,070$, karena $X_{\text {hitung }}^{2}<X_{\text {tabel }}^{2}$ dapat disimpulkan bahwa data sampel berasal dari populasi yang berdistribusi normal. Sedangkan untuk perhitungan kecerdasan intrapersonal diperoleh nilai $X_{\text {hitung }}^{2}=-34,009$ dan $X_{\text {tabel }}^{2}=11,070$, karena $X_{\text {hitung }}^{2}<X_{\text {tabel }}^{2}$ dapat disimpulkan bahwa data sampel berasal dari populasi yang berdistribusi normal dan perhitungan kedisiplinan belajar diperoleh nilai $X_{\text {hitung }}^{2}=-39,078$ dan $X_{\text {tabel }}^{2}=11,070$, karena $X_{\text {hitung }}^{2}<X_{\text {tabel }}^{2}$ dapat disimpulkan bahwa sampel berasal dari populasi yang berdistribusi normal.

Tabel 1. Statistik Deskriptif Kecerdasan Intrapersonal, Kedisiplinan Belajar, dan Prestasi Belajar Matematika

\begin{tabular}{cccc}
\hline $\begin{array}{c}\text { Statistik } \\
\text { Deskriptif }\end{array}$ & $\begin{array}{c}\text { Kecerdassan } \\
\text { Intrapersonal }\end{array}$ & $\begin{array}{c}\text { Kedisiplinan } \\
\text { Belajar }\end{array}$ & $\begin{array}{c}\text { Prestasi Belajar } \\
\text { Matematika }\end{array}$ \\
\hline Maksimum & 121 & 119 & 100 \\
Minimum & 80 & 64 & 48 \\
Rata-rata & 94,2 & 97,30 & 73,38 \\
Median & 94,74 & 97,94 & 75,14 \\
Modus & 96,24 & 98,50 & 78,44 \\
Varians & 72,25 & 129,17 & 139,93 \\
Simpangan Baku & 8,50 & 11,37 & 11,82 \\
\hline
\end{tabular}

Sumber: Data Primer yang Diolah 
Tabel 2. Ringkasan Hasil Uji Normalitas

\begin{tabular}{cccc}
\hline Variabel & $\boldsymbol{X}_{\text {hitung }}^{2}$ & $\boldsymbol{X}_{\text {tabel }}^{2}$ & Simpulan \\
\hline Kecerdasan Intrapersonal & $-34,009$ & 11,070 & Normal \\
Kedisiplinan Belajar & $-39,078$ & 11,070 & Normal \\
Prestasi Belajar Matematika & $-15,799$ & 11,070 & Normal \\
\hline
\end{tabular}

Sumber: Data Primer yang Diolah

Pengujian linieritas regresi dilakukan untuk menguji garis regresi antara variabel bebas dangan variabel terikat, apakah berpola garis lurus (linier) atau tidak. Pengujian linieritas regresi dilakukan dengan kriteria pengujian jika $F_{\text {hitung }}<F_{\text {tabel }}$ maka persamaan garis regresi berpola linier dan jika $F_{\text {hitung }}>F_{\text {tabel }}$ maka persamaan garis regresi tidak berpola linier. Dari perhitungan uji linieritas kecerdasan intrapersonal atas prestasi belajar matematika diperoleh $\mathrm{F}_{\text {hitung }}=0,79<\mathrm{F}_{\text {tabel }}=2,17$ dan kedisiplinan belajar atas prestasi belajar matematika diperoleh $\mathrm{F}_{\text {hitung }}=-0,47<\mathrm{F}_{\text {tabel }}=2,35$.

Tabel 3. Ringkasan Hasil Uji Linieritas Regresi

\begin{tabular}{cccc}
\hline Garis yang Diuji & $\mathbf{F}_{\text {hitung }}$ & $\mathbf{F}_{\text {tabel }}$ & Keterangan \\
& & & \\
\hline $\mathrm{X}_{1}$ atas $\mathrm{Y}$ & 0,79 & 2,17 & Linier \\
$\mathrm{X}_{2}$ atas $\mathrm{Y}$ & $-0,47$ & 2,35 & Linier \\
\hline Sumber: Data Primer yang Diolah & &
\end{tabular}

Sumber: Data Primer yang Diolah

Uji multikolinieritas menggunakan koefisien VIF (variance inflation factor), dimaksudkan untuk menguji hubungan antara variabel bebas yaitu kecerdasan intrapersonal dan kedisiplinan belajar. Pengujian multikolinieritas dilakukan dengan kriteria jika nilai VIF $<10$ maka tidak terjadi masalah multikolinieritas atau dengan kata lain, tidak terdapat hubungan kuat antar variabel bebas. Dan jika nilai VIF > 10 maka terdapat multikolinieritas. Dari hasil perhitungan uji multikolinieritas nilai VIF $=1,051<10$ dan nilai Tolerance $=0,951>0,1$; sehingga disimpulkan tidak terdapat multikolinieritas antara kecerdasan intrapersonal $\left(\mathrm{X}_{1}\right)$ dan kedisiplinan belajar $\left(\mathrm{X}_{2}\right)$.

Tabel 4. Ringkasan hasil uji Multikolinieritas

\begin{tabular}{cccc}
\hline Variabel & VIF $_{\text {hitung }}$ & VIF & Keterangan \\
\hline $\begin{array}{c}\text { Kecerdasan Intrapersonal } \\
\text { dan Kedisiplinan Belajar }\end{array}$ & 1,051 & 10 & $\begin{array}{c}\text { Tidak Terjadi Masalah } \\
\text { Multikolinieritas }\end{array}$ \\
\hline
\end{tabular}

Sumber: Data Primer yang Diolah

Setelah melakukan uji persyaratan analisis data, langkah selanjutnya dilakukan perhitungan pengujian hipotesis yaitu dengan analisis regresi ganda. Dari hasil pengolahan data diperoleh besar koefisien korelasi sebesar 0,551. Nilai ini mengindikasikan adanya korelasi yang kuat antara kecerdasan intrapersonal dan 
kedisiplinan belajar secara bersama-sama terhadap prestasi belajar matematika siswa. Besarnya koefisien determinan sebesar 30,36\% yang berarti sebesar 30,36\% prestasi belajar matematika dipengaruhi secara bersama-sama oleh tingkat kecerdasan intrapersonal dan kedisiplinan belajar, sedangkan sisanya dipengaruhi oleh faktor lain yang tidak dibahas dalam penelitian ini. Secara parsial, signifikansi setiap variabel bebas terhadap variabel terikat, berdasarkan hasil perhitungan uji lanjut (uji t) menunjukkan bahwa masing-masing variabel bebas diperoleh $\left|t_{\text {hitung }}\right|>t_{\text {tabel }}(2,50>2,0273$ dan 2,163 > 2,0273). Sehingga dapat disimpulkan bahwa individu setiap variabel bebas memberikan pengaruh positif dan signifikan terhadap variabel terikat.

Dari hasil perhitungan regresi ganda, diperoleh model persamaan yang terbentuk adalah $\widehat{Y}=27,263+$ $0,25 X_{1}+0,23 X_{2}$. Hal ini berarti, jika kecerdasan intrapersonal dan kedisiplinan belajar diabaikan, maka prestasi belajar matematika sebesar 27,263; setiap penambahan 1 poin kecerdasan intrapersonal akan menambah prestasi belajar sebesar 0,25 dan setiap penambahan 1 poin kedisiplinan belajar akan menambah prestasi belajar sebesar 0,23. Hasil uji signifikasi regresi ganda diperoleh $F_{\text {hitung }}>F_{\text {tabel }}(3,714>3,255)$, maka dapat disimpulkan bahwa terdapat pengaruh yang positif dan signifikan kecerdasan intrapersonal dan kedisiplinan belajar secara bersama-sama terhadap prestasi belajar matematika.

\section{PEMBAHASAN}

Berdasarkan data hasil penelitian dan hasil pengujian hipotesis, diperoleh hasil bahwa adanya pengaruh yang signifikan antara kecerdasan intrapersonal dan kedisiplinan belajar secara bersama-sama terhadap prestasi belajar matematika. Hal ini berarti, semakin tinggi tingkat kecerdasan intrapersonal dan kedisiplinan belajar siswa, akan semakin tinggi pula prestasi belajar matematika siswa. Hal ini disebabkan siswa yang memiliki kecerdasan intrapersonal akan jauh lebih bertanggung jawab terhadap dirinya sendiri sehingga siswa tersebut akan memiliki kesadaran dan tanggung jawab terhadap dirinya sendiri untuk terus memperbaiki dan meningkatkan kualitas belajarnya. Hal ini sesuai dari penelitian yang dilakukan oleh Koswara, dkk., (2015: 4) yang mengatakan bahwa: "Kecerdasan intrapersonal adalah kecerdasan yang berhubungan dengan kemampuan kesadaran diri, pengetahuan, pemahaman tentang perasaan, proses berpikir dan spiritual guna menghadapi dan menyelesaikan masalah".

Dari kesadaran diri itulah akan muncul sikap disiplin yang tinggi. Disiplin dapat membentuk sikap yang positif untuk terus berusaha belajar guna mendapatkan prestasi belajar yang baik pula. Hal ini sesuai dengan penelitan yang dilakukan oleh Supardi (2014: 86) yang mengatakan bahwa: "Perilaku disiplin belajar terutama muncul karena adanya kesadaran diri sendiri serta juga dapat muncul dorongan dari luar dirinya untuk mendapatkan prestasi belajar maksimal”. Hasil penelitian yang dilakukan Koswara, dkk., (2015: 6) adalah prestasi belajar siswa dapat ditentukan dan dilihat dari tingkat kecerdasan intrapersonal yang dimiliki setiap siswa. Sehingga bila siswa memiliki tingkat kecerdasan intrapersonal yang tinggi, maka siswa tersebut tidak akan kesulitan dalam prestasi belajar siswa tersebut. Selain itu hasil penelitian yang dilakukan oleh Supardi (2014: 86) mengemukakan bahwa: "Kedisiplinan belajar dan kecerdasan matematika logis memberikan dampak positif yang berarti terhadap prestasi belajar matematika siswa". Lebih lanjut "Agar 
peningkatan prestasi matematika menjadi lebih baik, dibutuhkan kesinambungan dari guru dan orang tua untuk membangun kedisiplinan belajar dan kecerdasan matematika logis yang baik bagi setiap peserta didik sehingga dapat menghasilkan prestasi belajar yang maksimal". Oleh sebab itu, guru harus mampu meningkatkan kecerdasan intrapersonal siswa melalui pembelajaran yang berbasis intrapersonal serta guru juga harus bisa meningkatkan dan mengajak siswa untuk memiliki sikap disiplin khususnya dalam belajar. Sejalan dengan itu, menurut Sefrina (Koswara, dkk., 2015: 6) yang mengemukakan cara-cara untuk mengembangkan kecerdasan intrapersonal, yaitu:

1. Lakukan pengaturan jadwal sehari-hari bersama anak.

2. Tetapkan target tersendiri pada satu tugas yang akan diberikan kepada anak.

3. Sediakan tempat tersendiri untuk anak belajar dan bermain.

4. Beri anak tugas atau proyek untuk meningkatkan motivasi dan kepercayaan diri.

5. Libatkan anak dalam kegiatan untuk meningkatkan motivasi dan kepercayaan diri.

6. Berikan buku khusus atau catatan harian untuk mencatat keberhasilan dan kegagalan yang pernah dilakukan.

Di sini peran guru sangat vital dalam merangkul siswa yang memiliki kecerdasan intrapersonal dan kedisiplinan belajar yang rendah. Setiap siswa memiliki tingkatan kecerdasan intrapersonal yang berbedabeda. Sebagian siswa ada yang memiliki tingkat kecerdasan intrapersonal yang sangat tinggi. Hal ini sudah merupakan bekal yang bagus untuk kesiapannya dalam belajar. Namun, jika guru tidak mampu mengarahkan siswa yang memiliki kecerdasan intrapersonal yang tinggi ini ke arah yang positif, maka bukan tidak mungkin siswa ini akan lebih cenderung bersikap buruk, seperti egois, sangat tertutup, sombong dan cenderung individualistik. Hal ini sesuai dengan pendapat Yaumi (2012: 177) yang mengatakan bahwa: "Jika sifat-sifat tersebut keluar dari koridor yang sebenarnya, dapat menyebabkan lahirnya perilaku-perilaku negatif seperti egois, mementingkan diri sendiri, terlalu protektif, curang pada orang lain, tidak rasional, berlebih-lebihan (over acting), kaku atau tidak fleksibel, lamban memberikan respons pada lingkungannya, dan sebagainya".

Berdasarkan hasil uji parsial diperoleh bahwa terdapat pengaruh yang signifikan antara kecerdasan intrapersonal terhadap prestasi belajar siswa. Dalam arti, semakin tinggi kecerdasan intrapersonal siswa maka akan semakin tinggi pula prestasi belajar siswa. Hal ini disebabkan siswa yang memiliki kecerdasan intrapersonal mampu intropeksi diri dan bertanggung jawab terhadap dirinya sendiri. Selain itu, siswa yang memiliki kecerdasan tersebut akan berpikir jauh lebih matang untuk apa yang akan dia lakukan di masa yang akan datang. Hal ini sesuai dengan pendapat Koswara, dkk., (2015: 6) yang mengatakan bahwa: "Orangorang yang berkecerdasan intrapersonal yang tinggi cenderung menjadi pemikir yang tercermin pada apa yang mereka lakukan dan terus menerus membuat penilaian diri”. Lebih lanjut mengatakan bahwa: "Kecerdasan ini lebih mengarah pada kemampuan penalaran, pengenalan pola abstrak, berpikir ilmiah dan penyelidikan, serta mampu mengerjakan perhitungan yang kompleks". Hal ini bisa menjadi bekal yang cukup baik untuk siswa dalam menghadapi suatu persoalan diproses pembelajaran khususnya pelajaran matematika yang membutuhkan berbagai pemecahan masalah.

Tidak dapat dipungkiri bahwa dengan meningkatnya kecerdasan intrapersonal siswa akan menumbuhkan kesadaran yang tinggi dan rasa tanggung jawab terhadap sesuatu terutama proses 
pembelajaran. Oleh karena itu, guru harus kreatif dalam melakukan pengajaran dan membimbing siswa di kelas agar siswa yang memiliki kecerdasan intrapersonal yang baik dapat diarahkan ke hal-hal yang positif. Berdasarkan hasil uji parsial antara kedisiplinan belajar dan prestasi belajar matematika adalah terdapat hubungan yang signifikan antara kedua variabel tersebut. Oleh sebab itu, siswa harus dibiasakan untuk disiplin terhadap sesuatu terutama dalam belajar. Karena dengan membiasakan sikap disiplin dalam proses pembelajaran akan memberikan manfaat dan jalan kepada siswa untuk sukses dalam belajar. Hal ini senada dengan Tu'u (dalam Supardi, 2014: 82) yang mengemukakan bahwa: "Disiplin merupakan jalan bagi siswa untuk sukses dalam belajar dan kelak ketika bekerja."

Pembinaan secara teratur dalam pembentukan disiplin sangat diperlukan. Hal ini disebabkan karena sikap disiplin seseorang adalah hasil pembentukan latihan yang didasari kesadaran pribadi yang dapat memberikan manfaat bagi dirinya sendiri maupun orang lain. Pembinaan sikap disiplin ini bisa ditanamkan di keluarga dan di sekolah. Hal ini sesuai dengan penelitian yang dilakukan oleh Rahman, (2012: 3) yang mengemukakan bahwa: "Disiplin dapat tumbuh dan dibina melalui latihan, pendidikan atau penanaman kebiasaan yang harus dimulai sejak dalam lingkungan keluarga, mulai pada masa kanak-kanak dan terus berkembang sehingga menjadi disiplin yang semakin kuat". Penanaman sikap disiplin di keluarga yang paling berperan dalam hal ini adalah orangtua. Orangtua harus bisa mengajarkan dan membiasakan anakanaknya untuk berdisiplin dalam melakukan sesuatu, terutama dalam hal belajar. Sementara itu, penanaman sikap disiplin di sekolah yang lebih berperan adalah guru. Guru harus menanamkan sikap disiplin yang baik kepada siswa di setiap proses pembelajaran. Oleh karena itu, dibutuhkan berbagai kreativitas baru bagi guru untuk menciptakan situasi pembelajaran di mana berbagai jenis kecerdasan peserta didik dapat dikembangkan, terutama kecerdasan intrapersonal. Selain itu, guru juga harus menanamkan sikap disiplin kepada siswa agar kemampuan dan kecerdasan yang dimiliki oleh siswa dapat berkembang secara optimal. Dengan demikian, upaya pengembangan kemampuan siswa dengan mengintegrasikan aktivitas pembelajaran berbasis intrapersonal dan penanaman sikap disiplin yang tinggi akan melahirkan generasi yang baik.

\section{SIMPULAN}

Simpulan dari penelitian ini, yaitu: terdapat pengaruh kecerdasan intrapersonal dan kedisiplinan belajar secara bersama-sama terhadap prestasi belajar matematika; terdapat pengaruh kecerdasan intrapersonal terhadap prestasi belajar matematika; dan terdapat pengaruh kedisiplinan belajar terhadap prestasi belajar matematika.

\section{DAFTAR RUJUKAN}

Adriyati, M. dan Nursa'adah, F. F. 2015. Pengaruh kecerdasan emosional dan kecerdasan intrapersonal terhadap berpikir kritis matematika peserta didik. Dalam Leonard dkk (Editor). Prosiding Seminar Nasional Pendidikan Matematika 2015. Vol 1: 389-394. Jakarta: Unindra Press.

Hamalik, O. 2001. Proses Belajar Mengajar. Jakarta: Bumi Aksara. 
144 Zefanya, F.

Koswara, A. R. dkk. (2015, February).Hubungan Antara Kecerdasan Intrapersonal Dengan Prestasi Belajar Pada Mata Pelajaran Pendidikan Kewarganegaraan.Retrieved November 28, 2015, from http://ejournal.unpak.ac.id.

Murizal, dkk. 2012. Pemahaman Konsep Matematis dan Model Pembelajaran Quantum Teaching. Jurnal Pendidikan Matematika, 1(1): 19-23.

Nenobahan, E. O. dkk. 2015. Peningkatan kemampuan analogi matematis siswa smp menggunakan metode pembelajaran penemuan terbimbing.Dalam Leonard dkk (Editor).Prosiding Seminar Nasional Pendidikan Matematika 2015. Vol 1: 94-99. Jakarta: UNINDRA Press.

Rahman, A. R. (2012, December 18). Pengaruh Motivasi, Lingkungan, dan Disiplin Terhadap Prestasi Belajar Siswa Pada Jurusan Teknik Audio Video SMK negeri 3 Yogyakarta. Retrieved Desember 12, 2015, from http://eprints.uny.ac.id/9495/

Slameto. 2013. Belajar dan Faktor-Faktor yang Mempengaruhinya.Jakarta: Rineka Cipta.

Siregar, Eveline dan Nara, Hartini. 2010. Teori Belajar dan Pembelajaran. Bogor: Ghalia Indonesia.

Supardi, U. S. 2014. Peran Kedisiplinan Belajar dan Kecerdasan Matematis Logis dalam Pembelajaran Matematika. Formatif: Jurnal Ilmiah Pendidikan MIPA, 4(2): 80-88.

Yaumi, M. 2012. Pembelajaran Berbasis Multiple Intelligences. Jakarta: Dian Rakyat

http://www.klikpositif.com/news/read/19703/singapura-peringkat-1-pendidikan-terbaik-dunia-indonesia69.html tanggal 13 mei 2015

http://news.metrotvnews.com/read/2014/10/23/309278/indonesia-juara-umum-olimpiade-matematika-dansains-di-india. 